Research Article

\title{
Analisis spasial dan faktor risiko tuberkulosis paru di Kecamatan Sidikalang, Kabupaten Dairi - Sumatera Utara tahun 2018
}

\author{
Spatial analysis and risk factors of pulmonary tuberculosis in \\ Sidikalang Sub-district of Dairi District - North Sumatra in 2018 \\ David Simbolon, Erna Mutiara², Rahayu Lubis ${ }^{3}$
}

\section{Abstract}

Dikirim:

15 Januari 2019

Diterima

25 Februari 2019
Background: Spatial analysis of TB cases is important to determine the distribution of cases and diffusion patterns so that appropriate allocation of health resources can be carried out. Spatial analysis has never been carried out in Sidikalang Sub District. Purpose: The purpose of this study was to map the distribution of pulmonary TB cases, to find out whether there was a cases clustering, buffer cases of pulmonary TB with health centers, distribution patterns, and the correlation between risk factors with the incidence of pulmonary TB. Methods: This research was an quantitative study with a matched case control design. The population is all patients with pulmonary TB and non pulmonary TB patients in Sidikalang. The mapping sample was 78 peoples and research sample was 116 peoples (58 cases and 58 controls).The sampling technique is purposive sampling. Data were obtained through interviews and position coordinates with Garmin Montana 680 GPS. Spatial analysis using SatScan v9.6, and statistical analysis with Epi Info 3.5.4, and overlays with QuantumGIS 3.0. Results: One cluster of pulmonary TB was found in the Subdistrict of Sidikalang. A total of $72(92.3 \%)$ cases were located at a distance of $>1$ $\mathrm{km}$ from the puskesmas. The diffusion pattern of pulmonary TB was contagious. Working status, nutritional status, smoking status, and contact history were found to be associated with the incidence of pulmonary TB. District health office was expected to to improve healthy lifestyle promotion especially for improving family nutrition, controlling smoking behavior, and maintaining a healthy environment. Conclusions: This spatial analysis found important evidence for the District Health Office in determining priority areas for pulmonary TB prevention in Sidikalang Sub-district. Optimizing screening for suspected TB, intensifying home visits and increasing clean and healthy lifestyle activities are key eradication of tuberculosis.

Keywords: Spatial analysis, tuberculosis, Sidikalang

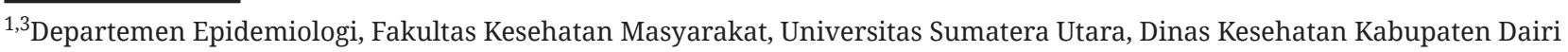

${ }^{2}$ Departemen Biostatistika dan Kependudukan, Fakultas Kesehatan Masyarakat, Universitas Sumatera Utara
} 


\section{PENDAHULUAN}

Proporsi kasus TB terbesar berada di wilayah Asia. Tujuh negara penyumbang 64\% kasus TB di dunia adalah India, Indonesia, China, Filipina, Nigeria, Pakistan, dan Afrika Selatan (1). Indonesia masuk dalam kelompok 30 high burden countries tertinggi di dunia. Indonesia berada pada peringkat 2 dari 7 negara penyumbang 64\% kasus TB di dunia (1). Insidens TB di Indonesia pada tahun 2016 diperkirakan sebesar 391 per 100.000 penduduk. Jumlah kasus TB yang ditemukan di Indonesia pada tahun 2016 sebanyak 351.893 kasus, meningkat sebesar $6 \%$ bila dibandingkan dengan kasus TB yang ditemukan pada tahun 2015 yakni sebanyak 330.729 kasus. Sumatera utara merupakan peringkat ke 5 sebagai provinsi dengan kasus TB terbanyak pada tahun 2016 dengan jumlah kasus mencapai 22.643 atau 6,4\% dari total kasus. Proporsi kasus TB pada laki-laki sebesar $64,7 \%$ dan pada perempuan sebesar 35,3\%. Jumlah kasus TB Paru BTA positif pada tahun 2016 dilaporkan sebanyak 14.614 kasus, 66\% pada laki-laki dan 34\% pada perempuan (2).

Peningkatan jumlah kasus TB disebabkan oleh penurunan sistem kekebalan tubuh yang disebabkan adanya infeksi HIV, malnutrisi, umur, diabetes, status ekonomi, merokok, konsumsi alkohol, polusi di dalam rumah yang berasal dari proses pembakaran, kepadatan hunian, dan riwayat kontak. Pengendalian faktor risiko TB ditujukan untuk mencegah/mengurangi penularan dan kejadian penyakit TB (3).

Kabupaten Dairi merupakan peringkat ke 10 dalam jumlah kasus TB terbanyak di Sumatera Utara dengan proporsi 2,1\% di tahun 2016. Kecamatan Sidikalang adalah penyumbang kasus TB terbesar di Kabupaten Dairi. Jumlah kasus TB di Kecamatan Sidikalang selama kurun waktu 3 tahun terakhir mengalami peningkatan. Berdasarkan data Profil Kesehatan Kabupaten Dairi jumlah kasus TB di Kecamatan Sidikalang pada tahun 2015 adalah sebanyak 85 kasus, pada tahun 2016 meningkat sebesar 3,5\% menjadi 88 kasus, dan pada tahun 2017 kembali mengalami peningkatan sebesar 10,2\% menjadi 97 kasus (4).

Analisis spasial dapat memetakan secara geografis sebaran penyakit berbasis wilayah (5). Data TB di Kabupaten Dairi belum berbentuk SIG. Pemetaan sebaran kasus belum dilakukan. Hal ini menyebabkan gambaran distribusi kasus TB berdasarkan wilayah di Kecamatan Sidikalang tidak diketahui secara pasti. Identifikasi dan analisis terhadap faktor risiko yang berhubungan dengan kejadian TB di Kecamatan Sidikalang juga sangat diperlukan, sehingga upaya pengendalian menjadi lebih optimal.

\section{METODE}

Penelitian ini adalah penelitian kuantitatif dengan desain penelitian berupa case control menggunakan matched case control berdasarkan jenis kelamin untuk mengkaji hubungan faktor risiko dengan kejadian TB Paru. Populasi adalah seluruh penderita TB Paru dan bukan TB Paru yang berada di Kecamatan Sidikalang tahun 2017. Sampel dalam penelitian ini terdiri dari sampel untuk pemetaan dan sampel untuk penelitian. Sampel untuk analisis spasial adalah seluruh penderita TB Paru yang tercatat pada aplikasi SITT (Sistem Informasi TB Terpadu) Dinas Kesehatan Kabupaten Dairi tahun 2017 dengan alamat yang lengkap dan dapat dilacak berjumlah 78 orang. Sedangkan untuk analisis hubungan/ korelasi terdiri dari sampel kasus dan kontrol. Teknik pengambilan sampel secara purposive sampling, sampel kasus adalah penderita TB Paru yang tercatat pada aplikasi SITT Dinas Kesehatan Kabupaten Dairi tahun 2017 yang memenuhi kriteria inklusi yakni data alamat jelas, umur $>15$ tahun dan bersedia menjadi responden penelitian berjumlah 58 orang, sedangkan sampel kontrol adalah orang yang bukan penderita TB Paru atau belum pernah menderita TB Paru, berusia > 15 tahun, memiliki jenis kelamin yang sama dengan kasus, bertempat tinggal dekat dengan kasus, dan bersedia menjadi responden.

Data primer adalah data faktor risiko yang diperoleh dari hasil wawancara terhadap kasus dan kontrol. Pengukuran di lapangan untuk menentukan titik koordinat kasus TB Paru maupun kontrol dengan menggunakan Global Positioning System (GPS). Data sekunder yang dipergunakan dalam penelitian ini meliputi data penderita TB pada SITT Dinas Kesehatan Kabupaten Dairi. Peta wilayah dan data kepadatan penduduk dari Badan Pusat Statistik Kabupaten Dairi.

Analisis spasial dilakukan untuk pemetaan sebaran kasus TB Paru di Kecamatan Sidikalang menggunakan software QuantumGIS 3.0, mengetahui ada tidaknya cluster TB Paru dengan purely spatial analysis menggunakan Software SatScan v9.6, mengetahui buffer jarak tempat tinggal kasus dengan Puskesmas, dan pola difusi Kasus TB Paru di Kecamatan Sidikalang. Selain itu, analisis hubungan juga dilakukan untuk menentukan hubungan antara faktor risiko TB dengan kejadian TB menggunakan uji McNemar pada software Epi Info 3.5.4.

Analisis bivariat dilakukan pada masing-masing variabel untuk mengetahui hubungan variabel yang diteliti dengan kejadian penyakit TB Paru. Uji statistik yang digunakan adalah uji McNemar (6). Penderita TB Paru adalah responden yang menderita TB Paru berdasarkan hasil pemeriksaan BTA dan rontgen yang tercatat pada SITT Dinas Kesehatan Kabupaten Dairi tahun 2017. Umur dikategorikan menjadi usia produktif (15-65 tahun) dan tidak produktif (<15 tahun dan $>65$ Tahun). Pendidikan diukur berdasarkan ijazah terakhir. Pekerjaan diukur dengan kegiatan untuk memenuhi kebutuhan hidup sehari-hari.

Status gizi diukur berdasarkan Indeks Massa Tubuh (IMT) yang diukur dengan cara berat badan dalam kilogram (kg) dibagi dengan tinggi badan dalam satuan 
meter kuadrat (m2) dikategorikan menjadi tidak berisiko (IMT $\geq 18,5 \mathrm{~kg} / \mathrm{m} 2$ ) dan berisiko $<18,5 \mathrm{~kg} / \mathrm{m} 2$. Status merokok adalah keadaan/kondisi responden yang dihubungkan dengan konsumsi rokok. Riwayat kontak adalah adanya interaksi dengan anggota keluarga serumah yang sudah diketahui menderita TB, dan menjalani terapi/pengobatan TB. Kepadatan hunian adalah perbandingan antara banyaknya penghuni rumah dengan luas lantai rumah berdasarkan informasi responden dikategorikan menjadi tidak padat $\left(\geq 9 \mathrm{~m}^{2} /\right.$ orang) dan padat (<9m2/orang). Penggunaan bahan bakar memasak adalah jenis bahan bakar untuk memasak yang digunakan sehari-hari oleh responden memenuhi syarat jika tidak menghasilkan asap dan tidak memenuhi syarat jika menghasilkan asap.

\section{HASIL}

Gambar 1 memetakan kasus TB Paru di Kecamatan Sidikalang pada tahun 2017. Hampir seluruh kelurahan/ desa terdapat kasus TB Paru kecuali Desa Kalang. Sebaran penderita yang berupa titik merah banyak ditemukan di Kelurahan Kota Sidikalang yakni sebanyak 23 titik, diikuti Kelurahan Batang Beruh sebanyak 17 titik, Desa Huta Rakyat sebanyak 9 titik, dan Kelurahan Sidiangkat sebanyak 8 titik. Terdapat 1 cluster TB Paru dengan pusat di 2.739740 LU, 98.324160 BT yakni di kelurahan Batang Beruh, dengan radius 2,63 Km dengan jumlah kasus sebanyak 31 kasus. Kelurahan Batang Beruh menunjukkan kepadatan penduduk terbesar kedua setelah Kelurahan Kota Sidikalang.

Selain itu, banyak tempat tinggal penderita TB Paru di Kelurahan Kota Sidikalang berdekatan dengan pusat pasar Kota Sidikalang yang kebanyakan hunian berbentuk rumah toko (ruko) yang rapat. Hasil observasi juga menunjukkan bahwa banyak rumah yang tidak memiliki ventilasi, dan pencahayaan yang cukup sehingga hal ini diduga meningkatkan risiko terkena penyakit TB Paru di daerah ini.

Gambar 2 menunjukkan peta buffer kasus TB Paru di Kecamatan Sidikalang tahun 2017. Buffer jarak tempat tinggal kasus TB Paru dengan Puskesmas menunjukkan bahwa sebagian besar kasus pada jarak lebih dari $1 \mathrm{~km}$ yakni sebanyak 72 kasus (92,3\%). Diagram ini menunjukkan temuan difusi kasus TB Paru di wilayah Kecamatan Sidikalang. Pola difusi yang terjadi menjelaskan terjadinya penambahan kasus baru dari waktu ke waktu, berdasarkan waktu (bulan) di beberapa area yang menunjukkan terjadinya transmisi kasus TB Paru terutama di Kelurahan Kota Sidikalang.

Selain itu, dengan analisis purely spatial menemukan 1 cluster TB Paru di Kecamatan Sidikalang. Cluster meliputi Kelurahan Bintang Hulu, Kelurahan Batang Beruh, Desa Kalang Simbara, Kelurahan Sidiangkat, dan Kelurahan Kota Sidikalang dengan jumlah kasus sebanyak 31 kasus.
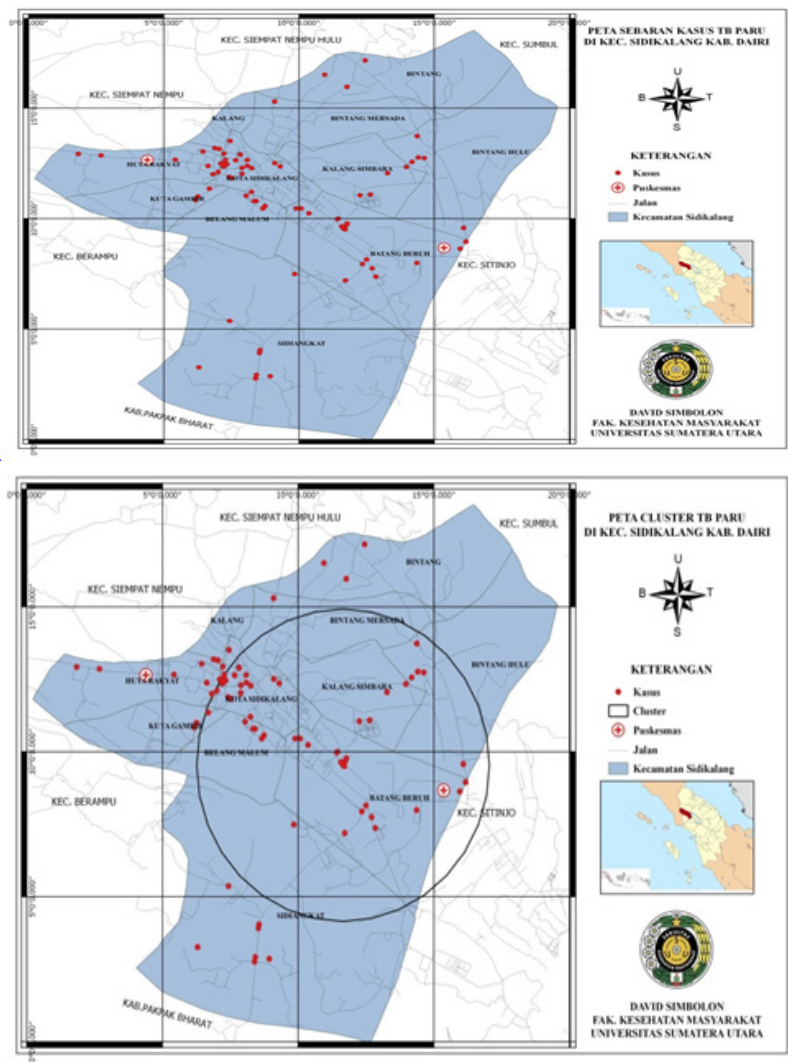

Gambar 1. Peta Sebaran Kasus dan Peta Cluster Kasus TB Paru di Kecamatan Sidikalang
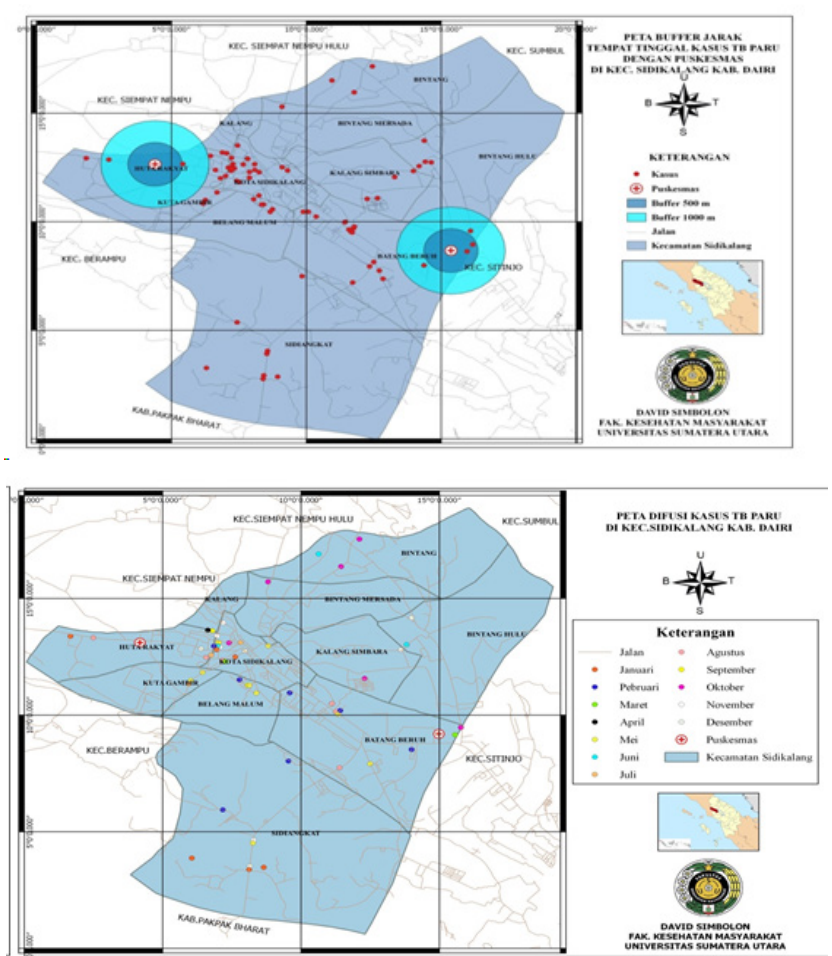

Gambar 2. Peta Buffer dan Difusi Kasus TB Paru di Kecamatan Sidikalang

Hasil ini didukung temuan bahwa kasus TB Paru lebih tinggi di 2 kelurahan yang memiliki jumlah penduduk terbesar yakni Kelurahan Kota Sidikalang dan Kelurahan Batang Beruh yakni sebesar 51,2\%. Kedua kelurahan ini saling berdekatan dan memiliki pemukiman yang 
cenderung mengelompok sehingga risiko penularan kasus menjadi semakin besar.

Gambar 3 menunjukkan peta overlay kepadatan penduduk dengan jumlah kasus TB Paru. Tiga wilayah dengan jumlah titik kasus terbanyak adalah dengan kepadatan yang cukup tinggi yakni Kelurahan Kota Sidikalang, Kelurahan Batang Beruh, dan Desa Huta Rakyat sedangkan 1 Kelurahan dengan kepadatan penduduk yang rendah tetapi menyumbang kasus TB Paru yang cukup besar yakni Kelurahan Sidiangkat.

Berdasarkan analisis spasial, terdapat difusi kasus TB Paru di wilayah Kecamatan Sidikalang. Pola difusi yang terjadi menjelaskan terjadinya penambahan kasus baru dari waktu ke waktu, berdasarkan waktu (bulan) di beberapa area yang menunjukkan terjadinya transmisi

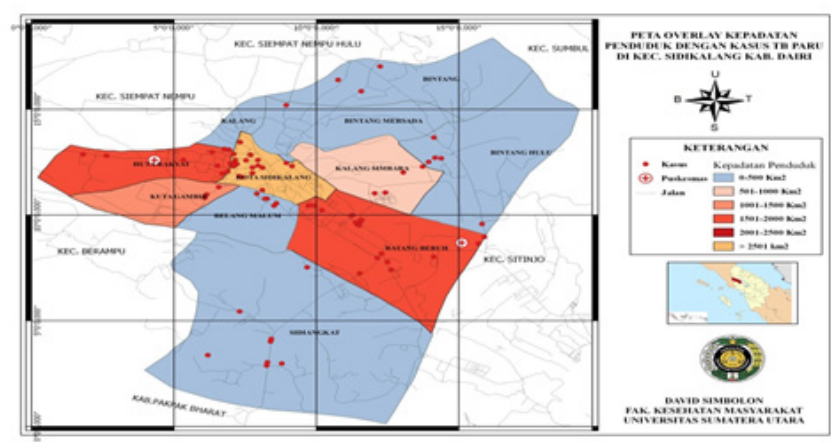

Gambar 3. Peta Overlay Kepadatan Penduduk dengan Kasus TB Paru di Kecamatan Sidikalang kasus TB Paru terutama di Kelurahan Kota Sidikalang dan kelurahan Batang Beruh. Kedua wilayah ini termasuk dalam wilayah cluster TB Paru di Kecamatan Sidikalang. Di Kelurahan Kota Sidikalang pada awal tahun hanya terdapat 3 kasus TB Paru selanjutnya pada akhir tahun menjadi sebanyak 23 kasus dan lokasi koordinat tempat tinggal kasus baru tidak terlalu jauh dengan tempat tinggal kasus pada awal tahun. Demikian juga pada kelurahan Batang Beruh pada awal tahun hanya terdapat sebanyak 1 kasus namun pada akhir tahun menjadi 17 kasus dan lokasi tempat tinggal kasus baru tidak terlalu jauh dengan kasus awal. Pola difusi yang terjadi adalah tipe contagious diffusion (difusi menular). Contagious Diffusion merupakan infeksi yang menyebar melalui kontak langsung dari suatu individu/host yang terinfeksi penyakit menular. Jarak sangat mempengaruhi proses penularan penyakit infeksius, sehingga jika seseorang memiliki kedekatan jarak dengan sumber infeksi akan memiliki probabilita yang jauh lebih besar untuk terinfeksi jika dibandingkan dengan individu atau wilayah yang jauh dari sumber penyakit.

\section{Analisis Faktor Risiko}

Tabel 1 menunjukkan hubungan variabel umur, pendidikan, pekerjaan, status gizi, status merokok, riwayat kontak, kepadatan hunian, dan penggunaan bahan bakar memasak dengan kejadian TB Paru. Variabel yang memiliki hubungan bermakna dengan TB Paru

Tabel 1. Faktor yang berpengaruh pada kejadian tuberkulosis paru di Sidikalang

\begin{tabular}{|c|c|c|c|c|c|c|}
\hline \multirow[b]{2}{*}{ Variabel } & \multicolumn{2}{|c|}{ Kontrol } & \multirow[b]{2}{*}{ p-value } & \multirow[b]{2}{*}{ OR } & \multicolumn{2}{|c|}{$95 \% \mathrm{CI}$} \\
\hline & $\begin{array}{c}E+ \\
n=58\end{array}$ & $\begin{array}{c}\mathrm{E}- \\
\mathrm{n}=58\end{array}$ & & & Lower & Upper \\
\hline \multicolumn{7}{|l|}{ Umur } \\
\hline Produktif $(\mathrm{E}+)$ & $48(82,8)$ & $5(8,6)$ & $1, \mathrm{OO}$ & 1,00 & 0,23 & 4,34 \\
\hline Tidak Produktif (E-) & $5(8,6)$ & $\mathrm{O}(\mathrm{O})$ & & & & \\
\hline \multicolumn{7}{|l|}{ Pendidikan } \\
\hline Rendah $(\mathrm{E}+)$ & $8(13,8)$ & $16(27,6)$ & 0,16 & 1,77 & 0,78 & 4,21 \\
\hline Tinggi (E-) & $9(15,5)$ & $25(43,1)$ & & & & \\
\hline \multicolumn{7}{|l|}{ Pekerjaan } \\
\hline Tidak Bekerja $(\mathrm{E}+)$ & $6(10,4)$ & $17(29,3)$ & $0,01^{*}$ & 3,40 & 1,25 & 9,21 \\
\hline Bekerja (E-) & $5(8,6)$ & $30(51,7)$ & & & & \\
\hline \multicolumn{7}{|l|}{ Status Gizi } \\
\hline Berisiko $(\mathrm{E}+)$ & $11(19,0)$ & $30(51,7)$ & $<0,001^{*}$ & 10,00 & 3,05 & 32,76 \\
\hline Tidak Berisiko (E-) & $3(5,2)$ & $14(24,1)$ & & & & \\
\hline \multicolumn{7}{|l|}{ Status Merokok } \\
\hline Merokok (E+) & $7(12,1)$ & $18(31,0)$ & $0,001^{*}$ & 6,00 & 1,76 & 20,36 \\
\hline Tidak Merokok (E-) & $3(5,2)$ & $30(51,7)$ & & & & \\
\hline \multicolumn{7}{|l|}{ Riwayat Kontak } \\
\hline Ada kontak $(\mathrm{E}+)$ & $1(1,7)$ & $8(13,8)$ & $0,01^{*}$ & 8,00 & 1,00 & 63,96 \\
\hline Tidak ada kontak (E-) & $1(1,7)$ & $48(82,8)$ & & & & \\
\hline \multicolumn{7}{|l|}{ Kepadatan Hunian } \\
\hline Padat $(\mathrm{E}+)$ & $5(8,6)$ & $2(3,5)$ & 0,41 & 0,50 & 0,04 & 3,48 \\
\hline Tidak padat (E-) & $4(6,9)$ & $47(81,0)$ & & & & \\
\hline \multicolumn{7}{|l|}{ Bahan Bakar Memasak } \\
\hline Tidak memenuhi syarat (E+) & $2(3,5)$ & $3(5,2)$ & 0,317 & 3,00 & 0,312 & 28,84 \\
\hline Memenuhi syarat (E-) & $1(1,7)$ & $52(89,6)$ & & & & \\
\hline
\end{tabular}

Ket: *Signifikan 
adalah pekerjaan, status gizi, status merokok, dan riwayat kontak. Orang dengan status gizi berisiko lebih tinggi 10 kali dibandingkan dengan orang dengan status gizi tidak berisiko. Orang yang ada riwayat kontak dengan penderita TB Paru lebih tinggi 8 kali dibandingkan dengan orang yang tidak ada riwayat kontak dengan penderita TB Paru.

Risiko menderita TB Paru adalah 3,4 kali lebih tinggi pada orang yang tidak bekerja dibandingkan dengan orang yang bekerja. Dalam penelitian ini dari 23 orang penderita TB Paru yang tidak bekerja sebesar 69,6\% memiliki status gizi berisiko, ini berarti penderita TB Paru yang tidak bekerja sulit memenuhi konsumsi makanan bergizi dikarenakan ketidakmampuan secara finansial. Sekitar 30,4\% penderita TB Paru yang tidak bekerja mengalami kontak serumah dengan penderita TB Paru sehingga meningkatkan risiko terkena TB Paru.

Orang yang merokok lebih tinggi 6 kali dibandingkan orang yang tidak merokok. Proporsi penyakit TB pada perokok cukup besar yakni sebesar 71,4\%. Dari 25 orang penderita TB perokok, $72 \%$ adalah perokok sedang dan $20 \%$ perokok berat. Hal ini perlu mendapat perhatian petugas kesehatan dalam edukasi penderita TB Paru agar berhenti merokok karena berpengaruh terhadap keberhasilan pengobatan penyakit TB Paru.

\section{BAHASAN}

Kelurahan Kota Sidikalang dengan jumlah kasus TB Paru terbanyak merupakan ibukota Kecamatan Sidikalang dan sekaligus ibukota Kabupaten Dairi. Menjadi pusat pemerintahan dan aktivitas perekonomian mengakibatkan Kota Sidikalang menjadi pilihan masyarakat dari berbagai wilayah Kabupaten Dairi untuk tinggal dan mencari pekerjaan. Hal ini berdampak terhadap tingginya kepadatan penduduk dan mobilitas yang tinggi sehingga risiko untuk menularkan dan tertular penyakit TB Paru menjadi semakin tinggi. Kenzie et.al. menyatakan bahwa keadaan hunian yang padat dan ditempati oleh berbagai macam orang seperti panti dan penginapan akan besar pengaruhnya terhadap timbulnya risiko penularan. Peluang terjadinya kontak dengan penderita TB Paru akan lebih besar di daerah perkotaan yang padat jika dibandingkan dengan daerah pedesaan (7).

Penelitian di Kota Manado menyatakan adanya hubungan kepadatan penduduk dengan kejadian TB Paru. Jumlah kasus TB Paru terbanyak ditemukan pada wilayah dengan kepadatan penduduk yang tinggi. Informasi mengenai pola penyebaran kejadian TB Paru dapat digunakan untuk menyusun strategi intervensi program kesehatan. Pola penyakit yang mengelompok dapat mempermudah petugas untuk melakukan intervensi program kesehatan dibanding dengan pola menyebar (8).

Berdasarkan analisis spasial, buffer jarak tempat tinggal kasus TB Paru dengan Puskesmas menunjukkan bahwa sebagian besar kasus pada jarak lebih dari $1 \mathrm{~km}$ yakni sebanyak 72 kasus (92,3\%). Kondisi ini menunjukkan adanya masalah aksesibilitas penderita TB Paru untuk mengakses layanan kesehatan, karena terkendala jarak yang cukup jauh dari pusat pelayanan kesehatan serta belum tersedianya sarana transportasi umum. Kondisi ini terkonfirmasi dengan adanya pengakuan dari kedua petugas TB Paru di wilayah Puskesmas Batang Beruh dan Huta Rakyat, yang menyebut terdapat kendala transportasi yakni tidak adanya kendaraan umum yang langsung menuju Puskesmas. Penderita dengan kondisi ekonomi miskin, kesulitan untuk melakukan kunjungan ke wilayah Puskesmas untuk memeriksakan diri secara tepat waktu. Selain itu zonasi penduduk peserta Jaminan Kesehatan Nasional (JKN) dengan fasilitas pelayanan kesehatan berdasarkan tempat tinggal juga masih belum tepat. Banyak penduduk mengeluhkan jauhnya akses dengan fasilitas kesehatan yang merupakan fasilitas kesehatan rujukan mereka padahal ada fasilitas kesehatan yang dekat dengan rumah mereka. Akses dengan fasilitas kesehatan merupakan permasalahan komplek yang meliputi berbagai aspek yaitu akses finansial, availabilitas berbagai jenis fasilitas kesehatan sesuai kebutuhan penderita, aksesibilitas geografis dan akseptabilitas penderita dengan fasilitas kesehatan (9).

Difusi Kasus. Informasi mengenai faktor yang mendukung penyebaran penyakit dapat diperoleh dengan mengetahui difusi dan pola sebaran penyakit. Waktu penularan, tempat penularan, dan populasi berisiko adalah beberapa informasi yang mungkin dapat diperoleh. Diketahuinya pola difusi suatu penyakit, faktor risiko, dan akses dengan pelayanan kesehatan maka diharapkan petugas kesehatan mengetahui pola umum penularan penyakit TB Paru sehingga mampu merencanakan intervensi yang sesuai kondisi setempat (10).

Noor menyatakan bahwa orang yang tidak bekerja akan mempunyai waktu lebih banyak kontak serumah dengan penderita TB Paru, sehingga akan lebih mudah menularkan penyakit TB Paru melalui kontak serumah dengan penderita TB Paru dibandingkan dengan orang yang bekerja. Jenis pekerjaan memengaruhi pendapatan keluarga yang berdampak pada pola konsumsi makanan, dan pemeliharaan kesehatan. Orang dengan pendapatan yang kurang lebih besar kemungkinan memiliki bangunan rumah yang tidak memenuhi syarat kesehatan sehingga akan mempermudah terjadinya penularan penyakit $(11,12)$. Penelitian di Manado menemukan bahwa risiko TB Paru pada pekerja 3 kali lebih tinggi dibanding orang yang tidak bekerja (11).

Temuan tentang efek status gizi didukung oleh penelitian Rukmini dan Chatarina di Indonesia yang menemukan ada hubungan antara status gizi dengan kejadian TB Paru. Risiko menderita TB Paru pada orang dengan status gizi kurang 2 kali lebih tinggi jika 
dibandingkan dengan status gizi normal (13). Hubungan infeksi TB Paru dengan status gizi telah diuraikan sejak 1950 (14). Penderita TB Paru mengalami peningkatan katabolisme protein yang ditunjukkan dengan ekskresi nitrogen dalam urine (15).

Temuan tentang efek rokok sesuai dengan penelitian Prihanti (2015) di Provinsi Jawa Timur yang melaporkan bahwa ada hubungan merokok dengan kejadian TB Paru. Risiko menderita TB Paru lebih tinggi 11,7 kali pada orang yang merokok dibandingkan dengan orang yang tidak merokok (16).

Temuan dalam hal riwayat kontak sejalan dengan penelitian Rukmini dan Chatarina (2010) di Indonesia menemukan bahwa risiko menderita TB Paru 4,35 kali lebih besar pada orang yang memiliki riwayat kontak serumah dengan penderita TB Paru dibandingkan dengan yang tidak punya riwayat kontak serumah dengan penderita TB Paru. Risiko penularan bertambah jika terdapat penderita TB Paru lebih dari 1 orang dalam 1 rumah tangga, dan besar risiko penularannya adalah 4 kali dibandingkan dengan rumah tangga yang hanya satu orang penderita TB Paru (13).

\section{SIMPULAN}

Wilayah dengan jumlah kasus TB Paru terbanyak adalah Kelurahan Kota Sidikalang (23 kasus), Kelurahan Batang Beruh (17 kasus), dan Desa Huta Rakyat (9 kasus). Ketiga wilayah ini dapat dijadikan wilayah prioritas penanggulangan penyakit TB Paru di Kecamatan Sidikalang. Temuan 1 cluster TB yang berpusat di Kelurahan Batang Beruh menuntut optimalisasi kegiatan skrining agar dapat mencegah penularan yang lebih besar pada populasi pada masa yang akan datang. Temuan buffer jarak terdekat dengan fasilitas pelayanan kesehatan yakni < $1 \mathrm{~km}$ sebanyak 6 kasus (7,7\%) dan $>1 \mathrm{~km}$ sebanyak 72 kasus (92,3\%) diharapkan dapat mengintensifkan kunjungan rumah bagi penderita TB sehingga status penderita TB Paru dapat terpantau dengan baik. Temuan pola difusi kasus yang menyebar (contagious diffusion) pada kasus TB Paru di kecamatan Sidikalang menuntut optimalisasi upaya penjaringan suspek sangat diperlukan. Pekerjaan, status gizi, status merokok, dan riwayat kontak ditemukan berhubungan dengan kejadian TB Paru di Kecamatan Sidikalang tahun 2018 oleh karena itu Dinas Kesehatan diharapkan dapat meningkatkan kegiatan promosi PHBS terutama untuk perbaikan gizi keluarga, penanggulangan perilaku merokok, dan menjaga lingkungan sehat.

\footnotetext{
Abstrak

Tujuan: Analisis spasial terhadap kasus TB penting dilakukan untuk mengetahui distribusi kasus dan pola difusi penyakit sehingga dapat dilakukan pengalokasian sumber daya kesehatan secara tepat. Namun demikian, analisis tersebut belum pernah dilakukan di Kecamatan Sidikalang. Penelitian ini bertujuan untuk pemetaan sebaran kasus TB Paru, mengetahui ada tidaknya cluster TB Paru, buffer kasus TB Paru dengan Puskesmas, difusi (pola sebaran) kasus TB Paru di Kecamatan Sidikalang, serta hubungan faktor risiko dengan kejadian TB Paru. Metode: Jenis penelitian adalah penelitian kuantitatif dengan desain matched case control. Populasi adalah seluruh penderita TB Paru dan bukan penderita TB Paru di Kecamatan Sidikalang. Sampel pemetaan berjumlah 78 orang dan sampel penelitian berjumlah 116 orang (58 kasus dan 58 kontrol). Teknik pengambilan sampel adalah dengan purposive sampling. Data diperoleh melalui wawancara dan posisi koordinat dengan GPS Garmin Montana 680. Analisis spasial menggunakan SatScan v9.6, analisis statistik dengan Epi Info 3.5.4, dan overlay dengan QuantumGIS 3.0. Hasil: Satu cluster TB Paru ditemukan di Kecamatan Sidikalang. Sebanyak 72 (92,3\%) kasus berada pada jarak $>1$ km dari puskesmas. Pola difusi TB Paru bersifat menyebar (contagious diffusion). Pekerjaan, status gizi, status merokok, dan riwayat kontak ditemukan berhubungan dengan kejadian TB Paru di Kecamatan Sidikalang tahun 2018 oleh karena itu Dinas Kesehatan diharapkan dapat meningkatkan kegiatan promosi PHBS terutama untuk perbaikan gizi keluarga, penanggulangan perilaku merokok, dan menjaga lingkungan sehat. Simpulan: Analisis spasial ini menemukan bukti penting bagi Dinas Kesehatan dalam menentukan wilayah prioritas penanggulangan TB Paru di Kecamatan Sidikalang. Optimalisasi penjaringan/ skrining suspek TB Paru, mengintensifkan kunjungan rumah dan peningkatan kegiatan promosi PHBS.
} 


\section{PUSTAKA}

1. World Health Organization. Global Tuberculosis Report 2017. 2017. 260 p.

2. Kemenkes RI. Profil Kesehatan Indonesia 2016; Profil Kesehatan Provinsi Bali. [Online] Kemenkes RI. Available from: http://www.depkes.go.id/resources/ download/pusdatin/profil-kesehatan-indonesia/ProfilKesehatan-Indonesia-2016.pdf

3. Narasimhan P, Wood J, MacIntyre CR, Mathai D. Risk Factors for Tuberculosis. Pulmonary medicine. [Online] Hindawi; 2013;2013. Available from: doi:10.1155/2013/828939 [Accessed: 20th April 2019]

4. Dairi D. Profil Kesehatan Kabupaten Dairi tahun 2016. Sidikalang: Kepala Dinas Kesehatan Kabupaten Dairi; 2017.

5. Achmadi UF. Manajemen Penyakit Berbasis Wilayah. [Online] Kesmas: National Public Health Journal. 2009. p. 147. Available from: doi:10.21109/kesmas.v3i4.217

6. Sullivan KM. Pair-Matched Case-Control Studies. 2008.

7. Kenzie J, Pinger R, Kotecki J. Kesehatan Masyarakat. Jakarta: Buku Kedokteran EGC; 2007.

8. Kuncoro A, Asrifuddin A, Akili RH. Analisis Spasial Kejadian Tuberkulosis Di Kota Manado Tahun 20142016. e-Journal Health. 2016; 1-8.

9. Mulyawan K, Suarjana K. Analisis Spasial Keberadaan Fasilitas Kesehatan Tingkat Pertama (FKTP) di Denpasar, Badung dan Tabanan. 2015; Available from: https://simdos.unud.ac.id/uploads/file_penelitian_1_ dir/ecaa567cd234207b971154a8928686f0.pdf [Accessed: 20th April 2019]
10. Rahmawati. Difusi Dan Pola Persebaran Kasus Chikungunya Di Rukun Warga 08, Kelurahan Grogol Kecamatan Limo, Kota Depok November 2011 -Januari 2012. [Bachelor's] Universitas Indonesia; 2012.

11. Patiro LA, Kaunang WPJ, Malonda NSH. Faktor Risiko Kejadian Tuberkulosis Paru di Wilayah Kerja Puskesmas Tuminting. Media Kesehatan. [Online] 2017;9(3). Available from: https://ejournalhealth.com/ index.php/medkes/article/view/358 [Accessed: 20th April 2019]

12. N. N. Epidemiologi. Jakarta: Rineka Cipta; 2008.

13. Rukmini R, W. CU. Faktor-Faktor yang Berpengaruh Terhadap Kejadian TB Paru Dewasa di Indonesia (Analisis Data Riset KesehatanDasar Tahun 2010). Buletin Penelitian Sistem Kesehatan. [Online] 2011;14(4 Okt). Available from: doi:10.22435/bpsk.v14i4 Okt.1369 [Accessed: 20th April 2019]

14. Scrimshaw NS, Taylor CE, Gordon JE. The American Journal of the Medical Sciences, Volume 237, 1959: Interactions of nutrition and infection. Nutrition reviews. 1990;48(11): 402-405.

15. Nurhanah, Amiruddin R, Abdullah T. Faktor Faktor yang Berhubungan dengan Kejadian Tuberkulosis Paru Pada Masyarakat di Propinsi Sulawesi Selatan 2007. Jurnal MKMI. 6 No. 4(Oktober 2010): 204-209.

16. Prihanti GS, Sulistiyawati, Rahmawati I. ANALISIS FAKTOR RISIKO KEJADIAN TUBERKULOSIS PARU. Saintika Medika:Jurnal Ilmu Kesehatan dan Kedokteran Keluarga. 2017;11(2): 127-132 